DOI: $10.17516 / 1997-1370-0841$

УДК 81'322:004.354

\title{
Code-Switching (Russian - English) in the Discourse of IT-Specialists from Moscow
}

\section{Margarita A. Burdygina*}

School of Philology, Higher School of Economics

Moscow, Russian Federation

Received 12.05.2021, received in revised form 30.07.2021, accepted 14.09.2021

\begin{abstract}
The paper proposes a linguistic approach to studying code-switching in IT discourse of Moscovian IT specialists. The topic is of special interest since nowadays code-switching dominates in a number of professional spheres such as informational technologies, marketing and telecommunications. It also becomes a new language for the modern generation and moreover, a necessary tool for establishing contacts and demonstrating community affiliation. This new code exists not only within workplaces but also beyond them, that is why the aim of the article is to present an in-depth research into how IT discourse shapes Russian digital language on the whole. The methodology used for research is the Matrix Language Frame Model by C. Myers-Scotton (1993). The language units, which are represented by code-switches, are also analyzed in terms of their syntactic, morphological features and pragmatic functions. The research carried among more than 200 IT-specialists provided a thorough understanding of linguistic features and pragmatic functions of the collected code-switches and what is more, proved the impact of the sociolect on the Russian digital language.
\end{abstract}

Keywords: code-switching, Russian language, English language, digital discourse, runglish, professional discourse.

Research area: linguistics.

Citation: Burdygina, M. A. (2021). Code-switching (Russian - English) in the discourse of IT-specialists from Moscow. J. Sib. Fed. Univ. Humanit. soc. sci., 14(10), 1581-1591. DOI: 10.17516/1997-1370-0841

(C) Siberian Federal University. All rights reserved

* Corresponding author E-mail address: mburdygina@hse.ru 


\title{
Переключение кодов между английским
}

\section{и русским языками \\ в дискурсе московских IT-специалистов}

\author{
М.А. Бурдыгина \\ Национальный исследовательский университет Высшая школа экономики \\ Российская Федерачия, Москва
}

\begin{abstract}
Аннотация. В статье рассматривается переключение кода с русского на английский язык в дискурсе IT-специалистов. Известно, что русско-английское переключение кода имеет место во многих профессиональных сферах, таких как маркетинг, бизнес аналитика, телекоммуникации и в других. Образуемый социолект интересен тем, что, развиваясь, он выходит за пределы профессиональных сообществ, тем самым формируя русскоязычный цифровой дискурс, присущий не только представителям перечисленных профессий. В статье объясняется механизм этого распространения профессионального языка в массы: так, исследование, проведенное среди более чем 200 представителей сферы информационных технологий, показало, что рассматриваемый социолект действительно оказывает влияние на развитие русского языка. Отобранные языковые единицы, представленные переключениями кода, анализируются с помощью Матричной Модели Языка К. Майерс-Скоттон (1993) и описываются с точки зрения их синтаксических, морфологических особенностей.
\end{abstract}

Ключевые слова: переключение кода, русский язык, английский язык, цифровой дискурс, рунглиш, профессиональный дискурс.

Научная специальность: 10.02.00 - языкознание.

Introduction

\section{Current linguistic situation among Russian speakers: causes and views}

Nowadays in terms of globalization the social aspects of the language functioning seem to become more important than it used to be before this moment of time. More Russian people regard the English language as a tool of crucial importance - both for communication and work. Spheres that use English on a regular basis become more popular-such as IT, marketing, financial analysis, which is followed by an increase in English usage among the speakers of Russian.

Now IT is considered to prevail on the market due to the fact that every enterprise of life-supporting value (banks, online stores, construction companies) obtains an IT department. Specialists who work there in most cases use English as a second language on a daily basis. It happens so because foremost, IT evolves predominantly in the Western where English is a native language for most speakers. Also, some specialists publish their research on the international platforms such as medium.com (URL: https://medium.com/) and participate in the annual international conferences and workshops, for instance, «Holy JS», «Tech week», «International conference on research challenges in information science».

Regarding the value of English, some companies («EPAM Systems», «Luxoft») offer their specialists on-site courses to keep up their language skills or at least discounts on such ones. It is worth mentioning that «EPAM Systems» was established in 1993 and now has offices in over 30 countries and in 14 Russian cities, whereas «Luxoft» - in over than 19 states and 5 Russian cities, and English is a key point in all the offices.

This situation entails some transformation in the Russian language. A big number of 
scholars consider the current linguistic situation in Russia to be a result of language contacts (Kazkenova, 2013; Krongauz, 2013, 2017; Kuzmina, Abrosimova, 2013; Levontina, 2010). Most scholars regard the changes to Russian as a natural process which occurs due to the cultural-economic situation; others (Krongauz, $2013,2017)$ call for leaving out lexical units of foreign origin and view the current process as language contamination.

\section{Russian-English code-switching as a linguistic issue}

As a result of the ongoing situation, numerous lexical units and grammatical constructions of foreign origin occur in the Russian language these days. This situation has always taken place, that is why there are such a lot of Latin, French, Greek loan words. The only difference is that they were borrowed long time ago and cannot be considered occasional insertions anymore. Therefore they are more a part of the Russian language rather than codeswitches.

According to C. Myers-Scotton (1993, 2002), these two sites constitute a continuum, where some foreign lexical units can be already included into dictionaries, whereas other ones occur only in oral speech and limited number of domains. For instance, such units as kontent (контент), pattern (nаттерн), pleilist (плейлист) can be regarded as loan words because they trace back to the period of 20002010 when they first occurred, now they are used frequently in both oral and written speech and can even be found in dictionaries. However, there are units of recent origin, such as hailaitit' (хайлатить), тепеdzhit' (менеджить), tolk (толк), which are not that popular and fixed.

These units constitute a certain code or sociolect which is represented by a mix of Russian and English, and more precisely, switching from Russian into English. The host language (or the dominant one) is Russian because it creates a morphological (prepositions, endings), whereas English is the so-called guest language which provides root morphemes and affixes.

This linguistic phenomenon can be viewed from different perspectives: one the one hand, it is connected with psycholinguistics if we look at how the mindset of speakers functions when they opt for this sociolect. On the other hand, this code can be analyzed in terms of linguistic characteristics and sociolinguistic ones.

Foremost, IT specialists themselves are those who are concerned with the language they use. Therefore, they make attempts to unify and classify IT sociolect by creating various glossaries (URL: https://ru.hexlet.io/blog/ posts/ponimaem-sleng-programmistov-minislovar-dlya-nachinayuschih-razrabotchikov). They define word accents, spellings and meanings, which, in their opinion, can assist beginners in the sphere of IT. Moreover, as it was found out during interviews, IT specialists frequently raise questions pertaining to normativity of their speech, so they encourage coworkers to pronounce words correctly and use set phrases properly.

A key point is that speakers of this sociolect use it not only at workplaces but also in colloquial everyday speech and a number of various domains, for instance, at homes. As a result, they create what can be called «Russian digital language» which goes far beyond online communication, because these days borders between online and offline communication are fading out. Eventually, a new code is formed, represented by extending discourse practices and semiotic means (Jones, Chik, Hafner, 2015: 190).

\section{Previous research and aims}

A major aim of the research is to take a closer look at how Russian and English come into contact with each other in IT discourse and prove that this sociolect extends to a number of domains apart from work. In order to fully describe IT discourse, the following points should be analyzed in detail:

- justification of using the term «codeswitching» for IT language practices;

- classification of the collected lexical units according to their syntactic, morphological and pragmatical functions;

- discussion of the domains where the digital language is used;

- identification of the speakers' attitude toward the vocabulary they use. 
Earlier this issue was analyzed by foreign linguists such as C. Myers-Scotton (1993, 2002), R. Skiba (1997), M. Clyne (2003), by Russian linguist A. Zhiganova (2014), who looked at the Russian-English code-switching in marketing in particular; and M. Isaeva (2009) analyzed Runglish in terms of media texts. There is a number of papers which examine the so-called «Russian computer discourse». However, they are rather outdated being concerned with the linguistic units that are actively used in the modern Russian language (avatar - aватар, gifka - гифка, smail смайл. guglit' - гуглить, fastfud - фастфуд, brend-бренд, trend-тренд, etc.) and are not considered to be something of an original kind anymore. Thus, they are not regarded as codeswitches anymore (nevertheless, they might be in the past).

Contemporary computer discourse (digital language) is being developed at the moment, which comprises words and collocations which are not seen in our speech on a daily basis. So what precisely is this new code is a topical issue.

Content of the article and hypothesis

Initially, the article discusses the notion of Runglish and its origin. It also focuses on C. Myers-Scotton's (1993) language frame model and argues that the lexical units found in IT discourse can be regarded as codeswitching. Thus, language frame model is applied to various units in order to test whether they correspond to all the key points of this framework:

- root morphemes originate from the guest language and all the other morphemes are taken from the host language;

- all the units are grammatically correct in Russian;

- doubled morphemes are frequently used as a part of code-switches.

The next stage includes a description of some syntactic and morphological features of the collected code-switches and major linguistic tendencies are presented; which is followed by pragmatical functions of code-switching in IT discourse.

Also, 200 individuals participated in the survey on how and why they code-switch and 20 interviews were conducted with IT spe- cialists. The article gives an overview on their opinions and demonstrates how communication of IT specialists forms a contemporary Russian digital language.

It is also supposed in the article that IT specialists' usage of digital language extends beyond the major domain, which is a workplace. Thus, the hypothesis is that IT industry and other connected spheres of studies transform the Russian language and create contemporary digital language, which spreads even among those who are not connected with informational technologies.

\section{Contribution of the research \\ to Russian linguistics}

Research pertaining to online or digital language dates back predominantly to 2000 2010, when the Internet communication was a relevantly new concept and the type of discourse used there was evolving. If we take a closer look at the research of that period, it is clear that at that time this kind communication was frequently called "computer discourse» due to the fact that the Internet used to be strongly associated with a device - computer itself (Podgornaya, 2008, Lepsheeva, 2009, Kasumova, 2009).

Consequently, lexical units analyzed by scholars were more related to computers and first means of online communication; the concepts which were novel ten years ago. Nevertheless, they are not new to us at present: chat (чат), messadzh (мессадж), уизег (юзер), imho (uмхо).

It was not until 2010 when linguists started referring to online discourse as «Internet language» or «digital language» (Fedorova, 2014, Gorina, 2016).

Most scholars who research digital discourse look at it in general (Samaricheva, 2001: Podgornaya, 2008: Lepsheeva, 2009: Kasumova, 2008: Chirsheva, 2015) without analyzing the origin of digital discourse, where it comes from and how it is formed. However, current research focuses on the sociolect which could, hypothetically, impact contemporary Russian digital language.

Also, this type of discourse is sometimes analyzed either in terms of language contam- 
ination (Krongauz, 2013, 2017) or in terms of «Internet discourse» without paying attention to its code-switching origin (Fedorova, 2014: Chirsheva, 2015: Gorina, 2016), whereas this research concentrates on code-switching.

Eventually, the research has been conducted for several years already, which helps to assess the process of language changes in time within a year or two; and it is of crucial importance because some of the collected lexical units (code-switches) remain in IT only, some of them go beyond to other domains and sometimes they even change their meanings.

\section{Data collection}

\section{and research process}

The research is being conducted in Moscow, among IT specialists. This very group of Runglish (that is how this new code is sometimes called) users was chosen at the outset of research, because their language is the most abundant in terms of English loan words.

Moreover, Runglish is a developing language: lexical units have a potential to be transformed there; its users often tried to codify it and compile a standardized glossary. Unfortunately, it seems to be a rather tough issue due to the fact that the language enhances every day and its users cannot update the glossaries in time.

The data (phrases which include codeswitches) is collected in the following way:

- listening to the job interviews;

- observing negotiations and meet-ups;

- communication with IT specialists both in formal and informal surrounding (workplaces and homes, meet-ups with friends respectively);

- listening to Russian podcasts for programmers, such as «Frontend Weekend», «Фротенд Юность», «uWebDesign»;

- watching IT conferences, such as «HolyJS»;

- reading position descriptions on the vacancies sites (URL: hh.ru);

- observing programmers' chats and online communities: «Love Frontend» (URL:

- https://vk.com/love_frontend), «Frontend Racoon» (URL: https://vk.com/jsraccoon);
- taking interviews with IT specialists (20 interviews), programmers' attitude towards code-switching is discussed alongside with in which types of extralinguistic situations they tend to code-switch;

- conducting a survey (200 respondents).

If any lexical units of non-Russian origin occur in the process of research, the phrases with them are included into the list of switches. Special attention is paid to memoing the units according to various tokens. Thus, the units are collected in the table where each unit is classified in terms of certain characteristics:

- $\quad$ speech part they belong to;

- morphological and phonetic variations (whether the units are always spelled in the same way or not; how they can be pronounced; whether they either have differences in meaning depending on the context or their meaning changes over time);

- frequency of usage;

- pragmatical functions (where they were used; whether they denoted some professional concepts or were used to express humour; what programmers themselves think of the reasons for using non-Russians words, etc.);

- stylistic features (colloquial, neutral, sophisticated).

On the whole, about 900 code-switches are collected at the moment, and the research is still in progress.

\section{Limitations of data representation in the article}

Only those code-switches will be presented as examples which follow the same pattern of formation (such as verbs, for instance, because they have a limited number of possible suffixes in Russian (such as -at' (-amb), -it' (umb), -yat' (-rmb), etc.) and thus, can be comprehended more easily not only by Russians but also by non-Russian readers. Originally, the research is full of all speech parts examples and collocations with them, nevertheless, it would be incomprehensible for the speakers of other languages due to a number of various patterns of formation.

Another limitation is connected with the frequency of certain words usage: in fact, it 
is far more difficult to measure frequency because I target predominantly phrases with code-switches and after collecting them, I can find out how many times a lexical unit occurs in the sampling. So it is worth examining a unit within a larger context: on the Internet on the whole (for instance, among Google enquiries) and in larger texts.

\section{Theoretical framework and discussion}

One of the major points to discuss is Runglish (mix of Russian and English) and which language concept it can be considered to belong to - whether Runglish operates loan words or code switches.

Some Runglish words can be regarded as the English loan words, especially words that every Russian individual uses in their everyday speech. I mean such lexical units as to google (гуглить), marketing (маркетинг), make ир (мейкап), image (имидж) in Russian. Most of the Runglish words cannot be considered loan words because they are not included in the Russian dictionaries and they are used far less frequently - mostly by the certain social and working groups and there are Russian analogues for most of them. Thus, they can be replaced by Russian words, however, speakers opt for English root morphemes due to numerous reasons which will be described later. There can be the following lexical units among the examples of Runglish: redirektit' (to redirect - перенаправлять), fichi (features - особенности), rezolvit' tasku (to resolve a task - pemamb задачy), etc. As it is clearly seen, despite the fact that there are Russian equivalents, occasionally Russian speakers prefer English forms.

Some scholars consider Runglish to be slang or jargon and that is, to some extent, true; however, this is more about stylistics than the nature, the origin of the Runglish itself.

By the way, the term «Runglish» was first coined by a cosmonaut - he called a language like that because cosmonaut's jargon contained words such as yuzer (user - пользователь), kopipast (copy paste - копировать и вставить), which have been already added to some Russian dictionaries; so they shifted from being code-switches to more regular and usual vocabulary of Russians and became loan words or the so-called «anglicisms».

To clear up the point, there will be some more examples given of the Russian-English verbs used in IT: fiksit' (to fix - фиксить), sabmitit' (to submit - caбмитить), hailaitit' (to highlight - хайлатить), mitigirivat' (to mitigate - митигировать), revjuit' (to review - ревьюить).

As we see and hear, they have a Russian ending of the verb (it' - ить) and also the English root which gives these words a meaning. All of them cannot be loan words because they are not fixed as such ones in the dictionaries, that is the main reason not to apply this name for the concept. At the same time, Myers-Scotton tends to support the idea that loan words and code-switching is a kind of continuum (1993). The units that used to be code-switches, sooner can become loan words after being fully accepted in the host language.

In fact, at this moment, the aforementioned words are more likely to be code-switching: according to Myers-Scotton's Matrix Language Frame Model (1993), one or two-word switches can be regarded as code-switching when the root morpheme originates from the guest language and all the other morphemes (affixes and endings) are taken from the host language otherwise, if a word lost its host language essence, it would be difficult to insert it into the Russian sentence. As a result, communication could fail.

Runglish cannot be considered the socalled «interference» (when two languages are mixed up in the speech process) because of the fact that «interference» is usually seen as something negative - when there are mistakes in one of the languages because of the impact of the other language. Russian-English codeswitching in IT cannot be regarded as a mistake because all the collocations are grammatically correct for Russians: for example, we can add Russian prefixes to the English words if needed and if it adds the certain shades of the meaning:

Chekat' - prochekat' (to check - чекатьпрочекать), rezolvit' - prorezolvit' (to resolve - резолвить - прорезолвить), parsit' rasparsit' (to parse - napcumb - pacnapcumb). 
In fact, all these words sound correct in Russian and they are formed and written according to the rules of the Russian language. So, there are prefixes like ras- (pac-) and raz (раз-) and according to grammatical rules of Russian, ras- is chosen if there is a voiceless consonant after it (for example, in raSparsit'); we choose raz-when it is followed by a voiced consonant. Thus, even spelling rules for code-switches are taken from the host language.

Apart from the verbs, there are also a big number of nouns such as kinouti (keynotes киноуты), with the Russian plural ending (-bl, -u); taski (tasks - таски), gaidi (guide гайды); manuali (тапиаl-мануаль). Also, all of the mentioned words are used in the sentence as if they were originally Russian words, so there is a typical Russian word order, which is also in compliance with the Matrix Language Frame Model.

Having paid attention to two key points of the Matrix Language Frame Model, I am moving on to its third principle: according to MyersScotton, in some words a speaker can use the so-called doubled morphemes - it happens when two morphemes have the same meaning both in the host language and the guest one (1993). It often happens with the code-switches that come from the English nouns in the plural form. So, as a result, a noun has two plural endings simultaneously: one is taken from English, another one is from Russian: fichizi (features фичизы) in Russian (English - $s$ remains, however, there is also a Russian plural ending -bl), ishjuzi (issues - ишьюзы), tulzi (tools - тулзы).

Talking about collocations, prepositions are usually of the Russian origin, too; the reason for this is that a preposition makes a collocation grammatically correct because it influences the case of the following word - and the Russian language has cases - that is why we can't use English prepositions, for example, in the phrase bit' $v$ prodakshene (to be in production - быть B продакшене). Thus, the main morphemes that give the phases their meanings, are again taken from the host language, which also corresponds with the Matrix Language Frame Model points.

However, there are some rare cases when English prepositions are used, and it happens especially with the idiomatic phrases which Russian speakers (IT speakers in particular), view as a unit rather than something separate. This occurs in the phrase zadacha $v$ in progrese (the task is in progress - задача в ин nрогресce) and in progress is a type of a task status for people who work in different IT spheres. Moreover, zadacha V IN progrese is an example of doubled morphemes due to the fact that both the Russian preposition $v$ (b) and the English one - in are used there.

Therefore, it is clearly seen that all the English words used in Russian speech are in compliance with Matrix Language Frame Model, that is why the aforementioned examples can be regarded as code-switching.

\section{Results}

\section{Syntactic features}

\section{of the Russian-English code-switches in IT}

One of the research aims is to find the most frequent syntactic patterns of code-switches which occur in IT discourse. The collected switches were classified in terms of their length and sentence placement. Grosjean (1982: 145) divided code-switches into

- words or insertions: sozdat' pul (to create a pull - создать nyл);

- collocations: developer tulz (developer tools - девелопер тулз);

- sentences: Poehal v Skandinaviyu? Right choice! (Have you gone to Scandinavia? Right choice! - Поехал в Скандивию? Верный выбор!)

The rarest ones are the last ones on the list - the so-called «islands of the guest language» which sometimes occur in the speech of Russian IT specialists: extent of complexity этой задачи зависит от...

They were rather rare compared to oneword switches (or insertions) which dominated in the research (about $90 \%$ of the sampling). One of the reasons for this is that programmers use the English language more as a tool for Russian communication and explanation of the IT concepts rather than a language for speaking. Thus, they kind of decompose English into the small units and then insert these units into Russian. Also, specialists predominantly need nominative units which describe concepts and 
processes (and in most cases, in English these words are shorter than in Russian, which is also convenient for speakers). Once a process is given a name, there is no need to tread any more information in English. That is the reason why one-word code-switches are the most frequent ones in Runglish.

In terms of placement in the sentences, most of the collected code-switches are intrasententional (or insertion) which takes place inside the structure of one word (they constitite 96 per cent of the sampling). Some of the lexical units are tag units. The later ones usually occur between parts of one and the same sentence. They can be linking words or vocatives such as meibi (maybe-мэйби), gaiz (guys - гайз). Tag units constitute 3 per cent of the collected data.

\section{Morphological features \\ of the Russian-English code-switches in IT}

The syntactic features that have just been described gradually shift out focus on the morphological ones. As it was mentioned, nominative units prevail in IT discourse. That is why about 68 per cent of the sampling consists of the nouns: prod (production - nрод), mitap (meetup - мuman), reliz (release - релиз), asesment (assessment - aсcессмент), komit (commit-коммит). In fact, they are least creative ones because they fully repeat the form of the same English word (the only difference is the Russian phonetic assimilation). In fact, more sophisticated lexical units occur sometimes. For instance, the ones that apply Russian diminutive suffixes: notifikashki (notifications - нотификашки).

Most of the noun-switches tend to be transformed into verbs such as relizit' (to release релизить), komitit' (to commit-коммитить), asesit' (to assess - acceccumb), which comprise about 20 per cent of the sampling. It is worth mentioning that all the Russian rules work in this cases. For instance, the so-called «interchange of the consonants» takes place when some consonants may change in one and the same root depending on the following sound. So, it happens to the verbs formed from the word bag (bug- бaz). It is typical of Russian to interchange [g] sound to [3] (zh) sound in some cases, so if we form the verb from bug, we get the word debazhit' (to debug - дебажить) with [3] sound. Thus, the root «ba» remains, but one sound is changed in it according to the host language phonetic rules which again corresponds with Matrix Language Frame Model principles.

There are only 5 per cent of adjectives in the code-switching sampling: oftopniy (offtop - oффртопный); kiling ficha (killing feature - киллинг фича); famil'yarnie zadaniуa (familiar tasks - фамильярные задания). The last one can considered to be a loan translation.

Adverbs constitute 2 per cent of the collected data, and are usually among the most creative ones: asap (ASAP - as soon as possible - как можно скорее); ро defoltu (by default - по дефолту); laitovo (light - легко, лаиттово). Also, adverbial code-switches are so rare because of the fact that it is more difficult to transform them so that they could be appropriate for Russian sentences. That is why speakers borrow roots for nouns, verbs, adjectives and add Russian suffixes and endings to them, whereas adverbs in Russian have a lot of patterns of formation (there various suffixes and endings exist). Therefore, making an adverb out of an English word takes more time and seems to be a creative process rather than a natural way of word borrowing.

\section{Pragmatical functions}

\section{of the Russian-English code-switches in IT}

Most of the code-switches obtain several pragmatical functions, that is why some functions can overlap one another.

The most frequent function of the collected code-switches is an informational function (80 per cent) - both in oral and written speech.

In a big number of cases English words are used for economy of the communicative means, due to the fact that in most cases English words and collocations are shorter. What is more, specialists who use English on daily basis save time and cognitive effort if they do not try to remember a Russian equivalent for a unit which they mostly hear in English rather than in their native language. Thus, 50 per cent of the sampling is related to the economy function. 
Humouristic function also takes place, especially in everyday oral communication and in most cases aims at the rarest cases of switching (hyperbolised forms or units that sound ridiculous for the Russian language). Function of emotions expression blends with humouristic one and both the constitute about 30 per cent of the code-switches.

Another point to mention is a selfidentification function: so, when a speaker uses both Russian and English and mixes them, they show their affiliation to the certain group or workplace. In case of programmers it demonstrates the workplace and the status, whereas when young people working in some other spheres code-switch in such a way, they represent their connection with the modern digital world.

Metalinguistic function occurs in the dialogues of IT specialists when they discuss language rules, pronunciations and collocations where certain lexical units may be used or not.

In terms of stylistic features of codeswitching, in most cases it is neutral (93 per cent), whereas some switches are used in highly colloquial contexts (4 per cent) and in the elevated speeches ( 3 per cent).

\section{Respondents' views}

\section{and digital language formation}

A survey was conducted pertaining to programmers' usage of English insertions in speech. 202 individuals took part in the survey. Also, 20 people were interviewed. It was discussed when and for what reasons IT specialists code-switch.

The data shows that digital language is predominantly influenced by Internet discourse. However, the term "digital language» entails not only online interaction. The authors of «Discourse and Digital Practices: Doing Discourse Analysis in the Digital Era» (Jones, Chik, Hafner, 2015: 190) regard digital language as a concept which borders are vague, because it exists in several dimensions, both in real and online communication.

Also the rise in the number of IT companies and professions impacts Russian digital language, which is a hypothesis of the current research.
In order to define whether the hypothesis is true, interviewees were asked:

- Why do you use English insertions?;

- When do you use them most frequently?;

- Do you spot the moments when you use an insertion?;

- Would you like to stop using English words in Russian?

The age of the youngest respondent was 16 , and the oldest one -45 years old. The group 25-35 years old prevailed in the research.

95 per cent of the interviewees claim that insertions occur in their speech. 70 per cent of them were somehow professionally connected with IT. It turned out that 85 per cent of people consider English words shorter and that is the reason why they use them. 42 per cent of the interviewees state that they tend to repeat some lexical patterns after some of their acquaintances. 27 per cent of individuals suppose that loan words make our speech more emotional and influential. About 8 per cent confirm that English vocabulary is trendy and make us sound smarter.

What is for the domains where insertions are used, more than 67 per cent of interviewees code-switch on a regular basis, either at work or in the family and among friends, which increases spread of IT discourse. Some of them state that there are situations when they forget a certain Russian word and use an English one instead.

Those interviewees who have families cite cases when their family members start repeating certain insertions after them. They also claim that they usually spot English words in their speech ( 80 per cent of individuals). It implies that their language choices are marked according to Myers-Scotton markedness model (1993). That means that they are predominantly used on purpose to create a certain impression.

Only 7 per cent of individuals would like to stop code-switching and speak Russian purely, whereas the rest regard English insertions as a natural process of language development.

\section{Conclusion}

Nowadays the topic seems to be a rather controversial subject. Nevertheless, most re- 
spondents see it as an essential part of the Russian language development.

English insertions that occur in IT discourse and those ones which evolve into digital Russian language can be considered to be code-switches according to the Matrix Language Frame Model because they comply with all the model's principles.

IT companies grow fast in Russia and more digital professions appear every year. That creates new concepts and therefore, words. Later, they are gradually leaking into a big number of spheres and workplaces and even into daily interaction. Thus, they be- come loan words: some of them can already be found in Russian dictionaries. There are also lexical units which obtain new meanings within a year or two. Thus, they become polysemantic. It confirms that code-switching in IT discourse is evolving.

Most of the interviewees accepted that they frequently code-switch among friends and relatives. Therefore, IT discourse spreads among those who are not connected with IT. Consequently, a common Russian digital language is formed which is used both online and offline. This data corresponds with the hypothesis of the research.

\section{References}

Auer, P. (1999). From codeswitching via language mixing to fused lects. Toward a dynamic typology of bilingual speech. International Journal of Bilingualism, 3(4), 309-332.

Auer, P. (2003). Code-Switching in Conversation: Language, Interaction and Identity. L., N.Y.: Routledge, $355 \mathrm{p}$.

Clyne, M. (2003). Dynamics of Language Contact - English \& Immigrant Languages. Cambridge University Press, $282 \mathrm{p}$.

Dabene, L. (1995). Bilingual speech of migrant people, «One speaker, two languages. Cross-disiplinary prospectives on code-switching» (L. Milroy \& P. Muysken, Eds.). Cambridge University Press, 17-44.

Fedorova, S. A. (2014). Zhanrovaya osobennost' Internet-diskursa [Genre features of the Internet discourse]. Social'no-Ekonomicheskie Yavleniya i Processy, 12, 330-335.

Gerard, L. D., \& Scarborough, D. L. (1989). Language-specific lexical access of homographs by bilinguals. Journal of Experimental Psychology: Learning, Memory, and Cognition, 15(2), 305-315.

Gorina, E. V. (2016). Podhody k analizu diskursa Interneta [Approaches to the analysis of Internet discourse]. Filologicheskie Nauki, Voprosy Teorii i Praktiki, 3-2(57), 73-76.

Grosjean, F. (1982). Life with Two Languages: An Introduction to bilingualism. Cambridge, Mass: Harvard University Press, $370 \mathrm{p}$.

Grosjean, F. (1995). A psycholinguistic approach to code-switching of guest words by bilinguals. One speaker, two languages. Cross-Disiplinary Prospectives on Code-Switching. Cambridge University Press, $259-275$.

Gumperz, J. J. (1982). Discourse Strategies (Studies in Interactional Sociolinguistics). Cambridge University Press, 225 p.

Harris, Z. (1952). Discourse analysis. Language, 28(1), 1-30.

Haugen, E. (1950). The Analysis of Linguistic Borrowing. Language, 26(2), 210-231.

Isaeva, M. G. (2009). Kodovye pereklyucheniya v pis'mennyh tekstah SMI (na primere russkoyazychnyh zhurnalov) [Code switches in written texts of mass media (on the example of Russian magazines)].

Jones, R. H., Chik, A., \& Hafner, C. A. (2015). Discourse and Digital Practices: Doing Discourse Analysis in the Digital Era. N.Y., Routledge, 250 p.

Kasumova, M. Y. (2009). Komp'yuternyj diskurs kak novyj vid kommunikacii [computer discourse as a new type of communication]. Vestnik KGPU Im. V.P. Astaf'eva, 3, 3-19.

Kazkenova, A. (2013). Ontologiya zaimstvovannogo slova [The ontology of the borrowed word]. Moskva, Flinta, Nauka.

Krongauz, M. (2013). Samouchitel' olbanskogo [Self-help guide of the Albany language]. Moskva, AST. 
Krongauz, M. (2017). Russkij yazyk na grani nervnogo sryva [The Russian language on the verge of a nervous breakdown]. Moskva, AST.

Kuz'mina, N., \& Abrosimova, E. (2013). Aktivnye processy v russkom yazyke i kommunikacii novejshego vremeni [Active processes in the Russian language and communication of the new time]. Moskva, Flinta, Nauka.

Lepsheeva, N. A. (2009). Zhanrovye osobennosti komp'yuternogo diskursa [Genre features of computer discourse]. Vestnik ChelGU, 43, 88-94.

Levontina, E. (2010). Russkij so slovarem [The Russian language with a dictionary]. Moskva, Azbukovnik.

Li, W. (1994). Three Generations, Two Languages, One Family: Language Choice and Language Shift in a Chinese Community in Britain (Multilingual Matters, 104). Multilingual Matters Ltd.

Ludi, G. (1992). The Dynamics of Languages in Contact- Linguistic, Sociolinguistic and Sociopolitical Aspects. Collection of Six Articles, Multilingua, 7-146.

Martin, J. M. (1995). Code-switching in the classroom: Two decades of research. (L. Milroy \& P. Muysken, Eds.). One Speaker, Two Languages, Cambridge, 90-111.

Myers-Scotton, C. (1993). Duelling Languages: Grammatical Structure in Codeswitching. Clarendon Press, Oxford, $304 \mathrm{p}$.

Myers-Scotton, C. (2002). Contact linguistics. Oxford University Press, 356 p.

Podgornaya, E. A. (2008). K voprosu o ponyatii komp'yuternogo diskursa [To the problem of the understanding of computer discourse]. Yazykovoe Bytie Cheloveka i Etnosa, 14, 193-198.

Poplack, S. (1980). Sometimes I'll start a sentence in English y termino en espafiol: toward a typology of code-switching. Linguistics, 18(7-8), 581-618.

Skiba, R. (2020). Code Switching as a Countenance of Language Interference. The Internet TESL Journal, 3(10), 1-11.

Zhiganova, A. V. (2014). Funkcional'naya specifika pereklyucheniya koda v sovremennyh diskursivnyh praktikah [Functional specifics of code changing in modern discourse practices]. Nizhegorodskij gosudarstvennyj lingvisticheskij universit im.Dobrolyubova. 